\title{
CURAHAN TENAGA KERJA KELUARGA DI USAHA TERNAK SAPI PERAH KASUS DI DESA PANDESARI, KECAMATAN PUJON, KABUPATEN MALANG, JAWA TIMUR
}

\author{
Budi Hartono'
}

\section{INTISARI}

Penelitian ini bertujuan untuk menganalisis curahan tenaga kerja keluarga di usaha sapi perah dan faktor-faktor yang mempengaruhinya. Pengambilan data dilakukan pada bulan Juli 2004. Jumlah responden sebanyak 127 peternak yang dipilih secara stratified random sampling dan dibagi menjadi tiga skala yaitu skala I ( 5 UT) sebanyak 79 peternak; skala II (antar 5-10 UT) sebanyak 36 peternak; dan skala III ( $\geq 10$ UT) sebanyak 11 peternak. Hasil penelitian menunjukkan bahwa curahan tenaga kerja keluarga di usaha sapi perah untuk skala usaha I, II dan III masing-masing adalah 226,77 JKSP/UT/tahun; 134,52 JKSP/UT/tahun; dan 68,69 JKSP/UT/tahun. Umur peternak sapi perah, pendapatan di luar usahatani dan luas lahan garapan berpengaruh negatif terhadap curahan tenaga kerja keluarga di usaha sapi perah. Jumlah anggota rumah tangga usia produktif dan jumlah sapi perah yang dipelihara berpengaruh positif terhadap curahan tenaga kerja keluarga.

(Kata kunci : Curahan tenaga kerja keluarga, Usaha ternak sapi perah).

Buletin Peternakan $29(2): 131-138,2005$

' Fakultas Peternakan Universitas Brawijaya Malang. 


\title{
THE TIME ALLOCATION OF THE FAMILY LABOR IN DAIRY FARMING CASE STUDY AT PANDESARI VILLAGE, PUJON DISTRICT, MALANG REGENCY
}

\begin{abstract}
The objectives of the research were to analyze the time allocation of the family labor in dairy farming and to identify the influencing factor on it. The study was conducted at Pandesari Village, Pujon District, Malang Regency, East Java Province in July 2004. One hundred twenty seven farmers were chosen as respondents by stratified random sampling which were divided into three scales. The first scale was $\leq 5 \mathrm{AU}$, the second scale was $5-10 \mathrm{AU}$, and the third scale was ( $\geq 10 \mathrm{AU})$, with the number of respondents according the scale were 79,36 and 11 farmers, respectivelly. The result showed that the family labor in dairy farming on the first scale, the second scale and the third scale were 226.77 working hours equivalent to man (JKSP)/UT/year, 134.52 working hours equivalent to man (JKSP)/UT/year and 68.69 working hours equivalent to man (JKSP)/UT/year, respectively. The time allocation of the family labor in dairy farming was negatively correlated with age of farmers, off farm income and width of land. There was phenomenon that the time allocation of the family labors was positively influenced by number of the productive family member and number of dairy animals kept by the household.
\end{abstract}

(Key words : Time allocation of the family labor, Dairy farming).

\section{Pendahuluan}

Pengembangan usaha peternakan sapi perah di pedesaan merupakan salah satu pembangunan sub sektor pertanian yang ditujukan untuk meningkatkan pendapatan serta kesempatan kerja pedesaan melalui peningkatan produksi susu sapi perah. Peningkatan produksi sebagai refleksi dari meningkatnya permintaan masyarakat diharapkan dapat mendorong terciptanya investasi baru, sehingga memungkinkan peningkatan kapasitas usahatani ternaknya. Lebih jauh adanya re-investasi dalam usahatani susu dan peternakan sapi perah dapat memberi dukungan terhadap pertumbuhan suatu wilayah (Taryoto dan Sunarsih, 1994).

Hasil penelitian Yusdja dan Iqbal (2000) melaporkan bahwa krisis ekonomi yang terjadi sejak tahun 1997 khususnya di Malang, Jawa Timur tidak menurunkan minat peternak untuk beternak sapi perah. Hal ini ditunjukkan dengan peningkatan pertumbuhan yang lebih cepat yaitu $3,85 \%$ pada tahun 1996 dan $4,76 \%$ pada tahun 1998, sedang daerah lainnya mengalami penurunan.

Ada beberapa faktor yang mempenganhi meningkatnya jumlah ternak maupun peternak sapi perah diantaranya adalah adanya jaminan dan kontinuitas perolehan pendapatan dari hasil penjualan susu segar, peternak mendapatkan insentif maupun bonus dari Koperasi dan Industri Pengolahan Susu (IPS) apabila kualitas susu lebih baik dari pada kualitas standard (Yusdja dan Iqbal, 2000) dan pasca krisis ekonomi menyebabkan hilangnya kesempatan kerja pedesaan di sektor luar pertanian, yang dapat diselamatkan disektor pertanian di pedesaan (Kasryno, 2000).

Lapangan pekerjaan di pedesaan terdiri dari jenis-jenis pekerjaan di sektor pertanian dan sektor non pertanian. Sektor pertanian khususnya Jawa Timur merupakan tempat bekerja sebagian besar penduduk pedesaan yang diharapkan dapat berperan penting dalam upaya meningkatkan kesejahteraan anggota masyarakat. Oleh karena itu kebijakan memperluas kesempatan kerja di sektor pertanian khususnya peternakan sapi perah sangat penting untuk menopang kehidupan masyarakat. Sementara perluasan kesempatan kerja di sektor non pertanian ternyata sangat terbatas terutama pada saat krisis ekonomi.

Berdasarkan latar belakang diatas maka dapat diidentifikasi permasalahan yang telah ada 
yaitu sebagian besar rumah tangga petani di daerah penelitian terlibat dalam usahatani sapi perah, baik sebagai kesempatan kerja maupun sebagai sumber pendapatan rumah tangga. Penelitian ini diharapkan dapat memberikan gambaran perihal besarnya peranan usahatani sapi perah dalam penyerapan tenaga kerja serta faktor-faktor yang mempengaruhi penyerapan tenaga kerja keluarga di sapi perah.

\section{Materi dan Metode}

Penelitian merupakan studi kasus yang dilakukan di Desa Pandesari, Kecamatan Pujon, Kabupaten Malang dengan pertimbangan bahwa daerah tersebut merupakan sentra produksi susu di Jawa Timur, populasi terbanyak dan pemilikan ternak beragam. Jumlah responden yang dijadikan peternak contoh adalah sebanyak 127 peternak yang dipilih secara acak bertingkat berdasarkan skala usaha yaitu skala I ( $\leq 5$ UT) sebanyak 79 responden, skala II ( antara 510 UT) sebanyak 36 responden dan skala III ( $\geq$ 10,00 UT) sebanyak 11 responden.

Pengumpulan data dilaksanakan pada bulan Juli 2004, dilakukan dengan teknik wawancara berdasarkan pertanyaan yang telah dipersiapkan. Variabel yang diharapkan dapat menjelaskan masalah tersebut adalah jumlah sapi perah, jumlah anggota rumah tangga usia produktif, luas lahan garapan usahatani, jumlah anggota rumah tangga, pendapatan rumah tangga non usahtani dan tenaga kerja keluarga pada usaha ternak sapi perah.

Analisis regresi linear berganda dengan metode two stage least square (2SLS) untuk menganalisis pengaruh variabel bebas terhadap variabel curahan tenaga kerja keluarga pada usaha ternak sapi perah. Pengolahan data dilakukan dengan program statistical system econometric (SAS). Hubungan antar variabel tersebut dilakukan dengan formulasi sebagai berikut:

$$
\begin{aligned}
\mathrm{Y}= & \mathrm{f}(\text { UPET, JARTP, JSP, PNUT, LLH) } \\
\mathrm{Y}= & \mathrm{a}+\mathrm{b}_{1} \text { UPET }+\mathrm{b}_{2} \text { JARTP }+\mathrm{b}_{3} \text { JSP }+ \\
& \mathrm{b}_{4} \text { PNUT }+\mathrm{b}_{5} \text { LLH }+\mathrm{b}_{6} \mathrm{D}_{4}+\mathrm{b}_{7} \mathrm{D}_{2}+\mathrm{b}_{3} \mathrm{D}_{3}
\end{aligned}
$$

Keterangan :

$$
\mathrm{Y}=\begin{aligned}
& \text { Curahan tenaga kerja keluarga pada } \\
& \text { usahaternak sapi perah (JKSP/thn). }
\end{aligned}
$$

UPET $=$ Umur peternak sapi perah (Tahun).

JARTP $=$ Jumlah anggota rumah tangga usia produktif(Orang).

JSP $=$ Jumlah ternaksapiperah(UT).

PNUT $=$ Pendapatan usaha non usahatani (Rp/tahun).

LLH $=$ Luas lahan garapan $(\mathrm{Ha})$.

$D_{1}=$ Dummy penguasaan sapi perah dengan nilai satu untuk skala usaha I dan nol untuk lainnya.

$\mathrm{D}_{2} \quad=$ Dummy penguasaan sapi perah dengan nilai satu untuk skala usaha II dan nol untuk lainnya.

$\mathrm{D}_{3} \quad=$ Dummy penguasaan sapi perah dengan nilai satu untuk skala usaha III dan nol untuk lainnya.

a $\quad=$ Intersep.

$b_{1.8}=$ Koefisien regresi.

\section{Batasan istilah}

1. Penguasaan ternak didasarkan dengan ukuran Unit Ternak (UT) yaitu anak sapi berumur 16 bulan setara dengan 0,25 UT, sapi muda (umur 1-2 tahun) setara dengan 0,5 UT dan induk sapi setara dengan 1 UT.

2. Curahan tenaga kerja pada usaha sapi perah adalah curahan jam kerja pada pekerjaan pengelolaan sapi perah yang diukur dengan satuan Jam Kerja Setara Pria (JKSP). Untuk laki-laki dalam satu hari terdapat $5 \mathrm{JKSP}$, perempuan $0,8 \times 5 \mathrm{JKSP}$ dan anak-anak : 0,5 $\mathrm{x} 5$ JKSP.

3. Jumlah anggota rumah tangga usia produktif yaitu semua orang dalam anggota rumah tangga dalam usia produktif yaitu umur 1564 tahun (Orang/responden)

4. Pendapatan rumah tangga adalah pendapatan keluarga rumah tangga peternak yang diperoleh dari usaha temak sapi perah, usahatani non sapi perah, penggunaan tenaga kerja dan remitan dengan satuan $\mathrm{Rp} / \mathrm{thn} / \mathrm{responden}$.

5. Pendapatan usaha ternak sapi perah (surplus sapi perah) adalah pendapatan bersih yang didapat oleh rumah tangga peternak dari hasil penjualan susu dan ternak dikurangi semua biaya produksi dalam usaha sapi perah (Rp/thn/responden) 


\section{Hasil dan Pembahasan}

Kecamatan Pujon sebagian besar penduduknya menggantungkan sumber pendapatan rumah tangga dari sektor pertanian. Usaha peternakan sapi perah dilakukan dalam bentuk peternakan rakyat dengan kepemilikan bervariasi mulai dari 1 (satu) ekor sampai 16 ekor per rumah tangga. Ternak utama yang diusahakan adalah sapi perah dari jenis Peranakan Friesien Holstain (PFH). Tanaman umum yang diusahakan oleh penduduk adalah sayuran seperti kubis, kol, wortel, selada, kentang, tomat, cabe dan palawija seperti jagung dan kacang-kacangan.

Hasil penelitian menunjukkan bahwa jumlah induk sapi yang dipelihara peternak sangat bervariasi yaitu mulai satu ekor sampai empat belas ekor yang dengan kontribusi pemilikan induk sapi 1-2 ekor sebesar $37,00 \%$, pemilikan induk sapi 3-4 ekor sebesar 45,67\% dan pemilikan induk sapi lebih dari 4 ekor sebesar $24,33 \%$. Dengan demikian pemilikan induk sapi perah di daerah penelitian terbesar dengan kontribusi pemilikan 3-4 ekor.

\section{Penguasaan lahan}

Lahan merupakan faktor produksi yang penting untuk proses usahatani pertanian dan peternakan di pedesaan. Lahan pertanian untuk usahatani tanaman pangan dan perkebunan berfungsi sebagai media untuk menanam berbagai jenis tanaman, sedangkan untuk ternak sapi perah merupakan media pakan hijauan dan tempat berdirinya kandang.

Hasil penelitian menunjukkan bahwa lahan yang dikuasai oleh rumah tangga peternak sapi perah di Desa Pandesari paling luas pada skala III yaitu $0,64 \mathrm{ha} /$ responden sedang paling sempit pada skala I yaitu $0,29 \mathrm{ha} /$ responden (Tabel 1).
Sempitnya luas lahan yang dikuasai oleh rumah tangga peternak sapi perah di Desa Pandesari merupakan salah satu ciri usahatani di Pulau Jawa. Hal ini sesuai pendapat Jayanata (1992), bahwa lahan untuk usahatani di negara berkembang umumnya sempit yaitu kurang dari satu hektar. Pada keadaan tersebut, rumah tangga petani dengan lahan sempit harus mencari nafkah sampingan seperti buruh, industri, dan sebagainya. Oleh karena itu usaha peternakan sapi perah di Desa Pandesari menganggap beternak sapi perah dijadikan sebagai pekerjaan utama dalam memperoleh pendapatan rumah tangganya.

\section{Jumlah anggota rumah tangga}

Hasil penelitian menunjukkan bahwa jumlah anggota rumah tangga antara 2 orang sampai 10 orang. Rata-rata jumlah anggota rumah tangga untuk masing-masing skala I, II dan III adalah 4,47 orang; 6,54 orang dan 4,44 orang (Tabel 2), atau secara agregat rata-rata jumlah anggota rumah tangga adalah 4,53 orang/responden.

Hasil statistik Indonesia tahun 2002 (BPS, 2003) menunjukkan bahwa jumlah anggota rumah tangga adalah 3,9 orang/ rumah tangga, maka jumlah anggota rumah tangga peternak sapi perah di daerah penelitian lebih besar dari angka Statistik Indonesia. Hal ini terjadi karena anggota rumah tangga peternak tidak seluruhnya berasal dari keluarga inti melainkan ada orang lain seperti orang tua, menantu, cucu atau saudara yang lain. Jumlah anggota rumah tangga sebagian besar termasuk dalam usia produktif masing-masing skala I, II dan III (Tabel 2) adalah $3,32(74,22 \%), 5,43(83,03 \%)$ dan $3,11(70,00$ $\%$ ) dengan demikian rumah tangga peternak sapi perah memiliki potensi curahan tenaga kerja rumah tangga yang lebih banyak.

Tabel 1. Rata-rata penguasaan lahan (Ha) (Average land occupation (Ha))

\begin{tabular}{lcc}
\hline \multicolumn{1}{c}{ Skala Usaha (Business scale) } & Sawah (Rice field) & Tegal (Field) \\
\hline Skala I (Scale I) & 0,08 & 0,21 \\
Skala II (Scale II) & 0,15 & 0,23 \\
Skala III (Scale III) & 0,33 & 0,34 \\
\hline
\end{tabular}


Tabel 2. Rata-rata jumlah anggota rumah tangga peternak sapi perah (Average number of family member of dairy farmer)

\begin{tabular}{lcccccc}
\hline \hline \multirow{2}{*}{$\begin{array}{c}\text { Skala usaha } \\
\text { (Business scale) }\end{array}$} & \multicolumn{2}{c}{$\begin{array}{c}\text { Usia produktif } \\
\text { (Productive age) }\end{array}$} & $\begin{array}{c}\text { Usia non produktif } \\
\text { (Non productive age) }\end{array}$ & \multicolumn{2}{c}{ Jumlah (Total) } \\
\cline { 2 - 7 } & $\begin{array}{c}\text { Orang } \\
\text { (person) }\end{array}$ & $\%$ & $\begin{array}{c}\text { Orang } \\
\text { (person) }\end{array}$ & $\%$ & $\begin{array}{c}\text { Orang } \\
\text { (person) }\end{array}$ & $\%$ \\
\hline Skala I (Scale I) & 3,32 & 74,22 & 1,15 & 25,88 & 4,47 & 100 \\
Skala II (Scale II) & 5,43 & 83,03 & 1,11 & 16,97 & 6,54 & 100 \\
Skala III (Scale III) & 3,11 & 70,06 & 1,33 & 30,06 & 4,44 & 100 \\
\hline
\end{tabular}

\section{Pemilikan sapi perah}

Pemilikan sapi perah beryariasi dari segi jumlah maupun komposisinya. Hasil penelitian yang ditunjukkan Tabel 3 memperlihatkan bahwa skala I, II dan III masing-masing adalah 3,6 UT; 7,4 UT dan 13,2 UT atau secara agregat rata-rata ternak yang dimiliki peternak adalah 5,59 UT. Apabila dibandingkan dengan hasil penelitian Santosa et al. (1997), bahwa pemilikan sapi setiap rumah tangga rata-rata 3,2 UT, maka jumlah ternak yang dipelihara di Pandesari lebih tinggi. Hal ini menunjukkan bahwa peningkatan jumlah ternak yang dipelihara merupakan pemanfaatan sumberdaya di pedesaan dan pengembangan sistem usaha ternak merupakan jawabannya, karena usaha ternak disamping sebagai sumber pendapatan melalui produksi susu, dan juga sebagai sumber pupuk organik yang berguna untuk kesuburan (Sudana, et al., 2002) serta dapat menyerap tenaga kerja di pedesan akibat dampak meningkatnya pengangguran (Kasryno, 2000; Taryoto dan Sunarsih, 1994).

Usaha peternakan sapi perah akan efisien apabila jumlah sapi produktif yang dipelihara lebih dari $60 \%$ dari populasi sapi perah yang ada dalam rumah tangga karena dengan pertimbangan tersebut dapat memenuhi biaya pemeliharaan sapi yang lain (Sudono, 1984). Hasil penelitian Tabel 3 menunjukkan bahwa peternak yang berada pada skala I dan III komposisi sapi produktif dan non produktif sudah cukup baik, namun untuk untuk peternak yang berada pada skala II kurang baik karena pada saat penelitian dilakukan ada beberapa peternak yang menjual ternaknya sedang induk pengganti yang dijual belum siap produksi.

\section{Curahan tenaga kerja rumah tangga di sapi perah}

Tabel 4 menunjukkan bahwa semakin banyak sapi yang dipelihara maka curahan tenaga kerja keluarga di usahatani sapi perah semakin efisien. Curahan tenaga kerja keluarga untuk sapi perah masing-masing skala I, II dan III adalah 226,77 JKSP/UT/tahun, 134,52 $\mathrm{JKSP} / \mathrm{UT} / \mathrm{tahun}$ dan $68,69 \mathrm{JKSP} / \mathrm{UT} / \mathrm{tahun}$ atau secara agregat rata-rata curahan tenaga kerja keluarga di sapi perah adalah 143,33 JKSP/UT/tahun.

Hasil penelitian Ihsan, et al. (2001), bahwa curahan tenaga kerja keluarga di usaha sapi perah adalah 138,17 JKSP per UT/tahun atau $679 \mathrm{JKSP} /$ tahun per responden. Hal ini berarti ada peningkatan jumlah tenaga kerja keluarga yang diserap dalam usaha sapi perah karena usaha ternak sapi perah lebih banyak ditujukan pada penciptaan lapangan kerja di pedesaan (Ilham dan Swastika, 2001) dan pasca krisis ekonomi menyebabkan hilangnya kesempatan kerja pedesaan di sektor luar pertanian, dapat diselamatkan disektor pertanian (Kasryno, 2000; Taryoto dan Sunarsih, 1994).

\section{Pendapatan rumah tangga peternak sapi perah}

Pendapatan rumah tangga peternak sapi perah umumnya sumber pendapatan utamanya dari usaha ternak sapi perah. Sumber pendapatan dari usahatani non sapi perah adalah hasil pertanian tanaman sayuran dan pendapatan non usahatani adalah pendapatan dari bukan usaha pertanian. Tabel 5 menyajikan sumber pendapatan peternak sapi perah. 
Tabel 3. Rata-rata komposisi penguasaan ternak (Compotion of dairy cattle kept by farmer)

\begin{tabular}{lcccccc}
\hline \multirow{2}{*}{$\begin{array}{c}\text { Skala usaha } \\
\text { (Business scale) }\end{array}$} & \multicolumn{2}{c}{$\begin{array}{c}\text { Ternak produktif } \\
\text { (Productive dairy cattle) }\end{array}$} & \multicolumn{2}{c}{$\begin{array}{c}\text { Ternak non produktif (Non } \\
\text { productive dairy cattle) }\end{array}$} & \multicolumn{2}{c}{ Jumlah (Total) } \\
\cline { 2 - 7 } & UT & $\%$ & UT & $\%$ & UT & $\%$ \\
\hline Skala I (Scale I) & 2,5 & 69,94 & 1,10 & 30,06 & 3,60 & 100 \\
Skala II (Scale II) & 4,2 & 56,76 & 3,20 & 43,24 & 7,40 & 100 \\
Skala III (Scale III) & 8,0 & 60,61 & 5,20 & 39,39 & 13,20 & 100 \\
\hline
\end{tabular}

Tabel 4. Rata-rata curahan tenaga kerja rumah tangga di sapi perah (jksp/ut/thn) (Average time allocation of labor for dairy farming)

\begin{tabular}{lc}
\hline Skala usaha (Business scale) & Curahan tenaga kerja (Labor time allocation) \\
\hline Skala I (Scale I) & 226,77 \\
Skala II (Scale II) & 134,52 \\
Skala III (Scale III) & 68,69 \\
\hline \multicolumn{1}{c}{ Rata-rata (Average) } & 143,33 \\
\hline
\end{tabular}

Besarnya sumbangan pendapatan usaha ternak sapi perah yang paling besar dalam sumber pendapatan rumah tangganya adalah rasional dan konsisten dengan bentuk usaha ternak sapi perah yaitu sebagai sumber pendapatan andalan dalam rumah tangga peternak sapi perah terutama pada skala usaha II dan III yang tampak usaha ternak sapi perah sudah merupakan usaha pokok dan utama (Tabel 5) karena kontribusinya melebihi dari $65 \%$ (Swastika, et al. 2000) dan usaha ternak sapi perah memberikan sumbangan pendapatan yang lebih besar dibanding usahatani padi (Susilowati, etal., 2002).

Faktor-faktor yang mempengaruhi curahan tenaga kerja keluarga di usaha sapi perah

Curahan tenaga kerja keluarga di usaha sapi perah diperkirakan dipengaruhi oleh faktorfaktor di dalam numah tangga sendiri seperti umur peternak, jumlah anggota rumah tangga usia produktif, jumlah sapi perah, luas lahan garapan dan pendapatan di luar usahatani. Hubungan antara besarnya curahan tenaga kerja keluarga di usaha sapi perah dengan faktor yang mempengaruhi dilakukan dengan analisis regresi linearyang tercantum dalam Tabel 6.
Tabel 6 menunjukkan bahwa usia peternak sapi perah mempunyai koefisien regresi negatif terhadap curahan tenaga kerja keluarga di sapi perah. Hal ini menunjukkan bahwa dalam usaha ternak sapi perah memerlukan lebih banyak tenaga kerja dalam bentuk fisik sehingga semakin tua usia peternak maka curahan tenaga kerja dalam sapi perah semakin berkurang karena semakin tua usia kondisi fisik seseorang semakin lemah.

Jumlah anggota rumah tangga usia produktif sebagai potensi tenaga kerja keluarga dan jumlah ternak sapi perah berpengaruh positif terhadap curahan tenaga kerja keluarga di sapi perah. Hal ini menunjukkan bahwa semakin banyak jumlah anggota rumah tangga usia produktif dan semakin banyak jumlah ternak sapi perah, maka curahan tenaga keluarga di usaha sapi perah semakin meningkat. Hal ini berarti bahwa anggota rumah tangga peternak lebih mengutamakan kerja di usaha sapi perah di banding usaha lain karena usaha ternak sapi perah sudah merupakan usaha pokok untuk menghasilkan pendapatan rumah tangga di daerah penelitian.

Pendapatan diluar usaha tani dan luas lahan garapan mempunyai koefisien regresi 
Tabel 5. Rata-rata sumber pendapatan rumah tangga peternak sapi perah (Rp/thn)

(Source of income family member of dairy farmer (Rplyear))

\begin{tabular}{lccc}
\hline \multicolumn{1}{c}{$\begin{array}{c}\text { Sumber pendapatan } \\
\text { (Source of income) }\end{array}$} & $\begin{array}{c}\text { Skala I } \\
\text { (Scale I) }\end{array}$ & $\begin{array}{c}\text { Skala II } \\
\text { (Scale II) }\end{array}$ & $\begin{array}{c}\text { Skala III } \\
\text { (Scale III) }\end{array}$ \\
\hline $\begin{array}{l}\text { Surplus sapi perah (Surplus of } \\
\text { dairy cattle) }\end{array}$ & $\begin{array}{c}\text { (S.934.106 } \\
\text { Persentase (\%) }\end{array}$ & 11.374 .741 & 27.076 .989 \\
$\begin{array}{l}\text { Surplus usahatani non sapi perah } \\
\text { (Surplus of non dairy cattle }\end{array}$ & $(53,70)$ & $(68,38)$ & $(86,81)$ \\
farming) & 954.564 & & \\
$\begin{array}{l}\text { Persentase (\%) } \\
\text { Pendapatan non usahatani }\end{array}$ & $(10,39)$ & 749.029 & 869.440 \\
$\begin{array}{l}\text { Income from off farm) } \\
\text { Persentase (\%) }\end{array}$ & 3.300 .059 & $(4,50)$ & $(2,79)$ \\
\hline $\begin{array}{l}\text { Jumlah (Total) } \\
\text { Persentase (\%) }\end{array}$ & $(35,91)$ & 4.510 .635 & 3.245 .455 \\
\hline
\end{tabular}

Sumber : Data primer diolah (2004) (Source: Primary data (2004)).

negatif terhadap curahan tenaga kerja keluarga di usaha sapi perah. Hal ini menunjukkan bahwa semakin sedikit pendapatan di luar usahatani dan semakin sempit luas lahan garapan maka semakin tinggi curahan tenaga kerja keluarga di usaha ternak sapi perah karena usaha ternak sapi perah sudah merupakan usaha pokok dalam rumah tangga. Dengan demikian konsisten dengan faktor produksi jumlah anggota rumah tangga usia produktif dan jumlah sapi perah yang dipelihara dalam rumah tangga.

\section{Kesimpulan}

Usaha ternak sapi perah merupakan alternatif untuk penyerapan tenaga kerja keluarga setelah krisis ekonomi dan mampu meningkatkan pendapatan rumah tangga. Jumlah anggota rumah tangga usia produktif dan jumlah ternak sapi perah yang dipelihara berpengaruh positif terhadap curahan tenaga kerja keluarga di usaha sapi perah.

\section{Daftar Pustaka}

BPS. 2003. Statistik Indonesia 2002. Jakarta. Ihsan, M.N., Z. Fanani, dan S. Wahyuningsih. 2001. Penyerapan Tenaga Kerja Wanita pada Usaha Sapi Perah di Kabupaten
Malang. Jumal Penelitian Ilmu Ilmu Sosial, Februari, Vol. 13. (1) : 14-19. Lembaga Penelitian Universitas Brawijaya, Malang.

Itham, N. dan D. K. S. Swastika, 2001. Analisis Daya Saing Susu Segar Dalam Negeri Pasca Krisis Ekonomi dan Dampak Kebijakan Pemerintah terhadap Usaha Peternakan Sapi Perah di Indonesia. Jurnal Agro Ekonomi, Vol. 19 (1) : 19-43. Edisi Mei 2001. Pusat Penelitian dan Pengembangan Sosial Ekonomi Pertanian, Badan Penelitian dan Pengembangan Pertanian, Departemen Pertanian, Bogor.

Jayanata, J. T. 1992. Tata Guna Tanah dalam Perencanaan Pedesaan Perkotaan dan Wilayah. Penerbit ITB, Bandung.

Kasryno, F. 2000. Sumberdaya Manusia dan Pengelolaan Lahan Pertanian di Pedesaan Indonesia. Forum Penelitian Agro Ekonomi, Vol 18 (1 dan 2) : 25-51. Edisi Desember. Pusat Penelitian dan Pengembangan Sosial Ekonomi Pertanian; Badan Penelitian dan Pengembangan Pertanian, Departemen Pertanian, Bogor.

Santosa, B. H, D. Wisadirana, dan S. Edi. 1997. Analisis Produktivitas Tenaga Kerja dan 
Tabel 6. Pendugaan koefisien parameter fungsi penyerapan tenaga kerja keluarga pada sapi perah di Desa Pandesari, Kecamatan Pujon, Kabupaten Malang, Jawa Timur (Parameter coeficent estimation of using the family labor function on dairy farming at Pandesari village, Pujon distric, Malang regency, East Java)

\begin{tabular}{lcc}
\hline \hline \multicolumn{1}{c}{ Variabel (Variable) } & $\begin{array}{c}\text { Koefisien regresi } \\
\text { (Regression coeficient) }\end{array}$ & $\begin{array}{c}\text { Probabilitas } \\
\text { (Probability) }\end{array}$ \\
\hline INTERCEP & 620,091703 & 0,0033 \\
UPET & $-1,849101$ & 0,7298 \\
JARTP & 2,899541 & 0,0098 \\
JSP & 59,619866 & 0,0008 \\
PNUT & $-0,000010$ & 0,3059 \\
LLH & $-0,880446$ & 0,8259 \\
$D_{1}$ & 810,916077 & 0,0048 \\
$D_{2}$ & 758,698512 & 0,0017 \\
$D_{3}$ & 662,932601 & 0,0079 \\
$\mathrm{R}^{2}$ & 0,843800 & - \\
\hline
\end{tabular}

Kesempatan Kerja Wanita pada Usaha Peternakan Sapi Perah. Studi di pedesaan Kabupaten Malang. Jurnal Penelitian Ilmu-Ilmu Sosial, Edisi Agustus. Vol. 9. (2). : 131-145. Lembaga Penelitian Universitas Brawijaya Malang.

Sudana, W., Hendiarto, Roesmiyanto, dan Al Gamal, 2002. Karakteristik Rumah Tangga Tani di Lima Agroekosistem Wilayah Pengembangan Sub di Jawa Timur. Jurnal Pengkajian dan Pengembangan Teknologi Pertanian, Edisi Juli, Vol. 5 (2) : 83-96. Pusat Penelitian Sosial Ekonomi, Pertanian. Badan Penelitian dan Pengembangan Pertanian, Bogor.

Sudono, A. 1984. Produksi Sapi Perah. Fakultas Peternakan, Institut Pertanian Bogor, Bogor.

Susilowati, S. H., Supadi dan C. Saleh. 2002. Diversifikasi Sumber Pendapatan Rumah Tangga di Pedesaan. Jurnal Agro Ekonomi. Edisi Mei. Vol 20 (1); 85-109. Pusat Penelitian Sosial Ekonomi Pertanian. Badan Penelitian dan Pengembangan Pertanian, Departemen
1. Sodikin. 2000. Dampak Krisis Ekonomi terhadap Prospek. Pengembangan Peternakan Sapi perah. Laporan Hasil Penelitian. Pusat Penelitian Sosial Ekonomi Pertanian, Badan Penelitian dan Pengembangan Pertanian, Departemen Pertanian, Bogor.

Taryoto, A. H dan Sunarsih. 1994. Kajian Ekonomi Usahatani Susu Sapi Perah Berdasarkan Status KUD di Jawa Barat dan Jawa Timur, Forum Penelitian Agro Ekonomi. Edisi Desember. Vol 12 (2) : 2437. Pusat Penelitian Sosial Ekonomi Pertanian. Badan Penelitian dan Pengembangan Pertanian, Departemen Pertanian, Bogor.

Yusdja, Y. dan M. Iqbal. 2000. Analisis Kebijakan Peningkatan Daya Saing Susu Sapi Perah setelah Krisis Moneter dalam Analisis dan Perspektif Kebijakan Pembangunan Pertanian Pasca Krisis Ekonomi, Monograph Series. No. 20 : 131-148. Pusat Penelitian Sosial Ekonomi Pertanian. Badan Penelitian dan Pengembangan Pertanian, Bogor. 